\title{
COMIMON BACTERIAL DISEASES OF FISH: PREVENTION AND CONTROL STRATEGIES
}

\author{
Sana Aziz ${ }^{*}$ and Sajid Abdullah \\ Department of Zoology, Wildlife and Fisheries, University of Agriculture, Faisalabad, Pakistan \\ *Corresponding author: sana.aziz1994@gmail.com
}

\section{INTRODUCTION}

Bacteria are common in the aquatic environment and fish in the captive environment are exposed to a phylogenetically diverse group of bacterial pathogens. The sustainable aquaculture industry is very important because $1 / 3^{\text {rd }}$ of the world's food comes from this industry (Ravi et al. 2007). To increase the aquaculture production, traditionally extensive fish farms have been changed to intensive ones and this intensification caused stress, which reduces the fish immunity and enhances their susceptibility to pathogenic bacteria. A disease outbreak can cause high mortality in fish that decreases their production, causing high economic loss to the fish farmers. In addition, sub-lethal diseases may affect growth rate and flesh quality and can cause undesirable visual changes. Factors that can cause infection in fish are not totally understood, but they may include: inadequate diet, poor husbandry techniques, alterations in the environment favoring the possible pathogens, reduction in resistance of the host animals to diseases, introduction of new fish species that are sensitive to local microbes or carry a microbe that is virulent to local populations. Proper understandings about the etiological agents, biochemistry, epizootiology and the relationship of stressrelated environmental component are necessary for effective management and control of diseases. The improvement in diagnosing tools can provide an opportunity to identify new infective agents (Colorni 2004). Many of the bacterial species present in the aquatic habitat are vital to the natural aquatic environment, with no direct effect in inducing fish disease. In the world, there are about 125 various species of 34 different families of bacteria that have been related to different fish infections. Most of the bacterial pathogens responsible for induction of diseases in fish are Gram negative rods, but some are 'Gram-Positive' rods, while a few are acid-fast rods in the aquatic ecosystem. Major bacterial pathogens of economically important fish are given in Table 1.

Bacterial populations in the environment affect not only the health status of fish stocks, but also increase public health concerns because fish and their products are the potent reservoirs of human infectious bacteria. Several bacterial species have been transmitted from fish to humans by eating raw or poorly cooked food or handling the affected fish. Human infections mainly depend on the time of year, contact of patient with fish and the environment, diet and the immunity of the exposed person. Control of infectious diseases in aquaculture is more complex than that of animal diseases of terrestrial environment due to difficulty in fish observation because fish are not close enough like terrestrial animals. The aquatic environment can favor quick disease transmission, fish catching can cause stress and disease in the fish is often difficult to identify and diagnose.

\section{'Gram-Negative Bacterial Diseases'}

Flavobacteriosis: Bacterial coldwater disease, bacterial gill disease and columnaris disease

Flavobacterial species are important fish pathogens. Species that induced significant losses in freshwater fish are Flavobacterium psychrophilum, Flavobacterium branchiophilum and Flavobacterium columnare, which are gram-negative, anaerobic and non-motile rods.

\section{Etiological Agents and Diseases}

F. psychrophilum causes rainbow trout fry syndrome (RTFS), bacterial coldwater disease (BCWD), peduncle disease, fry mortality syndrome, or low temperature disease and is also familiar as Flexibacter psychrophilus and Cytophaga psychrophila (Holt et al. 2012). Clinical signs are loss of appetite, listlessness, exophthalmia, eroded fin tips and skin, white patches on the fins, with some fish exhibiting fin rays separation, distension of abdomen with large volumes of ascites fluid, and pale colored gills (Cipriano and Holt 2005).

F. branchiophilum as a causative agent of bacterial gill disease was first reported by Davis (1926). The signs of disease are loss of appetite, lethargy, breathing at water top and fish will swim or present on the surface of water and orient in a "soldier-like" manner.

F. columnare causes columnaris disease (Declercq et al. 2013). This bacterium was formerly referred to as Chondrococcus columnaris, Bacillus columnaris, Flexibacter columnaris and Cytophaga columnaris. Affected fish may show lethargic behavior, loss of appetite, finrots and surface hanging. It includes both acute and long term infections and typically affects the gills, skin and fins. The disease is also known as "saddle-back disease" due to saddle-back like lesions. In tropical fish, due to these signs, the disease is also termed as "mouth fungus" or "cotton wool disease" (Bernardet and Bowman 2006).

\section{Geographical Distribution and Host Species}

Psychrophilum is known to expand constantly. The disease appears to occur in temperate regions. All salmonids and 
some non-salmonid species are probably affected. This pathogen was recognized for the first time in Mexico (Castillo et al. 2017) and Argentina in 2006.

F. branchiophilum emerged from Japan, Canada, Korea, United States, Hungary, Netherlands and India, it is common in cultured fish than in wild populations (Good et al. 2010). F. columnare has been documented mostly in freshwater fish (cultured and wild) of Africa, Europe, North and South America, Asia and Australia.

\section{Epizootiology}

F. Psychrophilum affects mostly juvenile fish and infection is also seen in smolts and yearlings. The actual entry mode of the organism is unknown. This disease often occurs when temperature of water is $12^{\circ} \mathrm{C}$ or below. Once infection occurred, expired fish serve as source of transmission of pathogens horizontally to other fish. This pathogen has an incontestable ability to adjust into different environments and maintain pathogenicity (Vatsos et al. 2001).

F. branchiophilum is transmitted horizontally from fish to fish. The outbreaks of infections are common in spring season and early summer, when the temperature of water rises. F. branchiophilum strains (virulent and avirulent) promptly stick to gill tissues and start colonization (Ostland et al. 1994).

F. columnare can affect fish of all ages but is more prevalent in young fish. It is also transmitted horizontally from fish to fish. Handling and injuries to the skin/ mucosa may predispose fish to columnaris disease. The severity and occurrence of columnaris disease is generally higher in warm water having temperature above $20^{\circ} \mathrm{C}$.

Edwardsiellosis: Edwardsiella septicaemia, enteric septicaemia of catfish

Edwardsiellosis is one of the infections of fish cultured in tropical side due to pathogenic Edwardsiella spp. (Park et al. 2012). The genus Edwardsiella consists of five species; $E$. ictaluri (Hawke 1979), E. tarda (Ewing et al. 1965), E. piscicida (Abayneh et al. 2013), E. hoshinae (Grimont et al. 1980) and E. anguillarum (Shao et al. 2015), all of which are Gram-negatives and belong to the Enterobacteriaceae family. Both E. tarda and E. ictaluri are most common and induce different infections; their characteristics are given in Table 2.

\section{Etiological Agents and Diseases}

Edwardsiella tarda causes Edwaredsiella septicaemia, which is also called as red disease of eels or emphysematous putrefactive disease of catfish. Loss of pigmentation, abnormal fluid buildup, severe haemorrhages, nodule formation, opacity of cornea, cutaneous lesions and necrosis during chronic infections are clinical signs of this disease.

\section{Enteric septicaemia}

Enteric septicaemia of catfish (ESC) and "hole-in-the-head disease" is caused by E. ictaluri. According to clinical signs, fish swim at the surface, and show external lesions, pale gills, exophthalmia, and ulceration. Two additional signs of the disease are acute septicaemia and chronic encephalitis.

\section{Geographical Distribution and Host Species}

E. tarda is found in both fresh and brackish water habitats. It has been reported from about 25 countries in Africa, Australia, North and Central America, Europe, Asia and the Middle East (Austin and Austin 1987). E. ictaluri agent has a narrow but diverse range of hosts in comparison to E. tarda. Experimental infections have been established in Salmonids. At least 40 fish species from more than 20 families are noted to have been infected by pathogenic $E$. tarda and approximately all fish species are prone to disease under favorable conditions.

\section{Epizootiology}

In Japan, E. tarda occurs in eels in the hot season at about $30^{\circ} \mathrm{C}$. In the spring season of Taiwan, the disease occurs in eels when water temperatures are unsteady between 10 and $18^{\circ} \mathrm{C}$. Edwardsiella septicemia in most fish species in the US seems to be increased by higher water temperatures $\left(30^{\circ} \mathrm{C}\right.$ and above) and the existence of high organic matter peculiarly in ponds of catfish. For $E$. ictaluri, primarily fingerlings and adult channel catfish may be affected by this disease, which results from the ingestion of pathogens from water.

\section{Enteric redmouth disease (ERM)}

It is an acute, as well as a chronic, bacterial disease caused by Yersinia ruckeri, a Gram-negative bacterial agent of Enterobacterium. Name of the disease "enteric redmouth" was used to differentiate it from aeromonad and pseudomon and infections that show similar pathological signs. Table 3 shows characteristics of enteric red mouth. According to clinical diagnosis, fish shows exophthalmia, skin darkening, subcutaneous hemorrhages of throat and mouth, enlarged spleen, redness and fluid in lower intestine. Degeneration of renal tubules and rise in melano-macrophages may be seen in diseased fish (Kumar et al. 2015).

\section{Geographical Distribution and Host species}

Y. ruckeri is present in the USA, Europe, South Africa, Australia and throughout the world, mainly in sites where salmonids are cultured intensively. Many invertebrates of aquatic habitat also have been found to possess $Y$. ruckeri infection.

\section{Epizootiology}

In small fish, this disease is acute, but in larger fish it occurs in chronic form. Fish that hold up disease can become asymptomatic carriers, which afterwards shed numbers of cells, hence, causing pathogen transfer within a group of fish. The severity of an outbreak increases dramatically under the unfavorable rearing situation, and also when animals are under stress. 
Table 1: Major bacterial pathogens of economically important fish

\begin{tabular}{|c|c|}
\hline Gram-negative aerobic rods & Name of the disease \\
\hline Flavobacterium psychrophilum & Coldwater disease \\
\hline Flavobacterium branchiophilum & Bacterial gill disease \\
\hline Flavobacterium columnare & Columnaris disease \\
\hline \multicolumn{2}{|l|}{ Gram-negative facultatively anaerobic rods } \\
\hline Edwardsiella tarda & Edwardsiella septicaemia \\
\hline Edwardsiella ictaluri & Enteric septicemia of catfish \\
\hline Yersinia rukeri & Enteric redmouth disease \\
\hline Vibrio anguillarum & Vibriosis \\
\hline Vibrio salmonicida & Coldwater vibriosis \\
\hline Aeromonas salmonicida & Furunculosis \\
\hline Aeromonas hydrophila & Septicemia \\
\hline Aeromonas caviae & Septicemia \\
\hline Aeromonas sobria & Septicemia \\
\hline Photobacterium damselae Piscicida & Photobacteriosis or pasteurellosis \\
\hline \multicolumn{2}{|l|}{ Gram-positive bacteria aerobic rods } \\
\hline Renibacterium salmoninarum & Bacterial kidney disease \\
\hline \multicolumn{2}{|l|}{ Gram-positive facultatively anaerobic rods } \\
\hline Enterococcus seriolicida / Lactococcus garvieae & Enterococcosis/ Lactococcosis \\
\hline Streptococcus spp. & Streptococcusis or septicaemia \\
\hline Weissella ceti & Weissellosis \\
\hline \multicolumn{2}{|l|}{ Acid fast rods } \\
\hline Mycobacterium spp. & Mycobacteriosis \\
\hline Nocardia asteroides & Nocardiosis \\
\hline \multicolumn{2}{|l|}{ Intracellular parasites } \\
\hline Piscirickettsia salmonis & Piscirickettsiaceae \\
\hline Piscichlamydia salmonis & Epitheliocystis \\
\hline Francisella spp. & Francisellosis \\
\hline
\end{tabular}

Table 2: Morphological and biochemical characteristics of two Edwardsiella spp. E. tarda and E. Ictaluri (Hawke et al. 1981; Farmer and McWhorter 1984; Waltman and Shotts 1986; Plumb and Vinitnantharat 1989; OIE 2006).

\begin{tabular}{|c|c|c|}
\hline Characteristics & E. tarda & E. Ictaluri \\
\hline Gram stain & Gram-negative & Gram-negative \\
\hline Morphology & Small straight rod & Small pleomorphic rod \\
\hline Growth condition & Facultative anaerobes & Facultative anaerobes \\
\hline Edwardsiella isolation media (EIM) & Black & Green \\
\hline Acid from: glucose, maltose, mannose & + & + \\
\hline Mannitol, sucrose, trehalose, L-Arabinose, Xylose, Rhamnose & - & - \\
\hline Nitrite from nitrate & + & + \\
\hline Lysine and ornithine decarboxylase, gas from glucose & + & + \\
\hline \multicolumn{3}{|l|}{ Tolerance to $\mathrm{NaCl}$} \\
\hline $1.5 \%$ & + & + \\
\hline $4.0 \%$ & + & - \\
\hline \multicolumn{3}{|l|}{$\mathrm{H}_{2} \mathrm{~S}$ Production } \\
\hline Peptone iron sugar, Triple sugar iron & + & - \\
\hline Mol $\% \mathrm{G}+\mathrm{C}$ of DNA & $55-58$ & $56-57$ \\
\hline
\end{tabular}

\section{Vibriosis}

\section{Etiological Agents and Diseases}

Vibriosis is a disease caused by bacteria of genus Vibrio. The disease is also known as boil disease (Kubota and Takakuwa 1963), salt-water furunculosis (Rucker 1963) and ulcer disease (Bagge and Bagge 1956). The two spp. of genus Vibrio are more important; Vibrio anguillarum causes vibriosis and Vibrio salmonicida causes coldwater vibriosis or hitra disease. The external signs of the disease include lethargy, weight loss and red spots on the fish and dark swollen lesions on skin that can bleed and ulcerate, causing exophthalmia. The infection spreads so rapidly in acute epizootics and fish die without exhibiting any particular disease signs (Austin and Austin 2007). The coldwater vibriosis is differentiated by extended ascites, which further causes visceral hemorrhages. The characteristics of Vibrio species, $V$. anguillarium and Vibrio salmonicida, investigated by Wiik and Edidius (1986), are given in Table 4 .

\section{Epizootiology}

The waterborne infection is the main source of transmission of pathogens. Bacteria are continuously released from the vent and open lesions. A common entry site is by the integument with the gills. Coldwater vibriosis typically occurs when temperature of water is less than $10^{\circ} \mathrm{C}$. 
Table 3: Morphological and biochemical characteristics of enteric red mouth.

\begin{tabular}{lc}
\hline Characteristics & Y. ruckeri \\
\hline Gram stain & Gram-negative \\
Morphology & Small straight rod \\
Growth condition & Facultative anaerobes \\
Substrate Utilization & \\
Adonitol, Arabinose, Cellobiose, Galactose, Lactose, Inositol, Dulcitol, Erythritol, Esculin, Melibiose, Raffinose, - \\
Rhamnose, Starch, Sucrose, Xylose & + \\
Trehalose, Mannitol, Maltose & $+(17 \%+$ gas $)$ \\
Glucose & + \\
Lysine and ornithine decarboxylase, & \\
Enzyme reaction & \\
Aesculinase, Chitinase, Cytochrome oxidase, Chondroitin sulfatase, Deoxyribonuclease, Fibrinolase, Elastinase, - \\
Caseinase & $+(51 \%)$ \\
Catalase, Beta-galactosidase, Lipase & + \\
Arginine dihydolase & $+(59 \%)$ \\
$\mathrm{H}_{2}$ S Production & - \\
\hline
\end{tabular}

$+=$ Positive, - = Negative.

Table 4: Morphological and biochemical characteristics of two Vibrio species, V. anguillarium and V. salmonicida .

\begin{tabular}{lll}
\hline Characteristics & V. anguillarium & V. salmonicida \\
\hline Gram Stain & - & - \\
Morphology & Motile rod shaped & Non-motile Rod shaped \\
Growth condition & Facultative anaerobes & Facultative anaerobes \\
Arginie dihydrolase & + & - \\
Voges-Proskauer reaction & + & - \\
Grow at $40^{\circ} \mathrm{C}$ & - & - \\
Utilization of L-arabinose and D-sorbitol & + & - \\
Reduction nitrate into nitrite & + & - \\
\hline
\end{tabular}
$+=$ Positive, $-=$ Negative

\section{Aeromonads Diseases: Furunculosis and Motile Aeromonads Septicaemia}

\section{Furunculosis}

\section{Etiological Agents and Diseases}

The causative agent of furunculosis is Aeromonas salmonicida. Among warm water and marine species, this variant also produces goldfish ulcerative disease, trout ulcer disease, carp erythrodermatitis and systemic infections. At the species level, four subspecies of $A$. salmonicida were recognized in the Bergeys Manual of Determinative Bacteriology (Holt et al. 1994), based on their differential properties. These are: masoucida, achromogenes, smithia and salmonicida. The main characteristics of $A$. salmonicida are given in Table 5 . The darkened skin, lethargy, development of furuncles or boils on the musculature and skin with loss of appetite are clinical signs of the disease. After acute infection, fish showed necrotic lesions of the epidermis with rapid septicemia.

\section{Geographical Distribution and Host Species}

This disease has been recorded in Africa, Europe, Asia, North and South America. However, it is usually related to freshwater fish, but marine fish are also susceptible (Shotts 1994).

\section{Epizootiology}

The exact mechanism of transmission is not entirely understood. However, it is known that the pathogen can be transmitted horizontally both within and among populations of fish, and is present at low level in carrier fish. Susceptible fish can acquire furunculosis (within 4 to 12 days; at water temperatures of $20^{\circ} \mathrm{C}$ ), after viable bacteria are discharged into their water supply. Chronic infections develop at temperatures below $13^{\circ} \mathrm{C}$. There is some evidence that the organism can be transmitted in seawater.

\section{Motile Aeromonads Septicaemia (MAS)}

\section{Etiological Agents and Diseases}

The causative agent of Motile Aeromonas Septicemia (MAS) is any of three species belonging to genus Aeromonas, including A. hydrophila, A. sobria. (Ingulis) and $A$. caviae. Characteristics of different species of motile Aeromonas are given in Table 6 . These all species are usually known as motile aeromonads and the disease is also known as "tail and fin rot" due to presence of fin rots (Fig. 1), ulcer disease, haemorrhagic septicaemia and redsore disease (Thiyagarajan et al. 2014). Ulcerations, exophthalmia, haemorrhage, superficial lesions, abscesses and lesions in internal organs (liver and kidneys) are the major signs of MAS (Garcia et al. 2007). 
Table 5: Morphological and biochemical characteristics of Aeromonas salmonicida.

\begin{tabular}{|c|c|}
\hline Characteristics & Aeromonas salmonicida \\
\hline Gram-Stain & Gram-negative \\
\hline Growth condition & Facultative anaerobes \\
\hline Morphology & $\begin{array}{l}\text { Non-motile rods with rounded ends } 1.3^{-} \\
2.0 \mu \mathrm{m} \text { by } 0.8-1.3 \mu \mathrm{m}\end{array}$ \\
\hline $\mathrm{H}_{2} \mathrm{~S}$, Indole, Voges-Proskauer, and acid production from sucrose & - \\
\hline Methy red test & + \\
\hline $\begin{array}{l}\text { Arginine dihydrolase, D-Glucose acid and gas, D-Mannitol acid, D-Galactose acid, } \\
\text { L-Arabinose, Maltose acid, Trehalose acid, Lipase and brown pigment production }\end{array}$ & + \\
\hline
\end{tabular}

$+=$ Positive, $-=$ Negative

Table 6: Morphological and biochemical characteristics of different species of motile Aeromonas (Woo and Bruno 2011).

\begin{tabular}{lccc}
\hline Characteristics & A.hydrophila & A. caviae & A. sobria \\
\hline Gram-Stain & - & - & - \\
Growth condition & Facultative anaerobes & Facultative anaerobes & Facultative anaerobes \\
Morphology & Rods shaped & + & Rod shaped \\
Motility & + & + & + \\
Voges-Proskauer reaction & + & - & - \\
Aesculin hydrolysis & + & + & + \\
CAMP like factor (aerobic only) & + & - & - \\
Pyrazinamidase activity & + & + & + \\
Mannitol, sucrose fermentation and Indole production & + & - & - \\
H2S Production & + & $\mathrm{R}$ & + \\
Arabinose fermentation & $\mathrm{V}$ & $\mathrm{R}$ & $\mathrm{R}$ \\
Lysine decarboxylase & + & $\mathrm{R}$ & $\mathrm{R}$ \\
Ampicillin susceptibility & $\mathrm{R}$ & - \\
Carbenicillin susceptibility & $\mathrm{R}$ & - \\
Cephalothin susceptibility & $\mathrm{R}$ & - \\
Ornithine decarboxylase & - & + & - \\
Lysine decarboxylase & + & - & + \\
Arbutin hydrolysis & + & + \\
Gas from the glucose & + & + \\
\hline
\end{tabular}

R=Resistant, S=Susceptible, V=Variable, + = Positive, - = Negative.

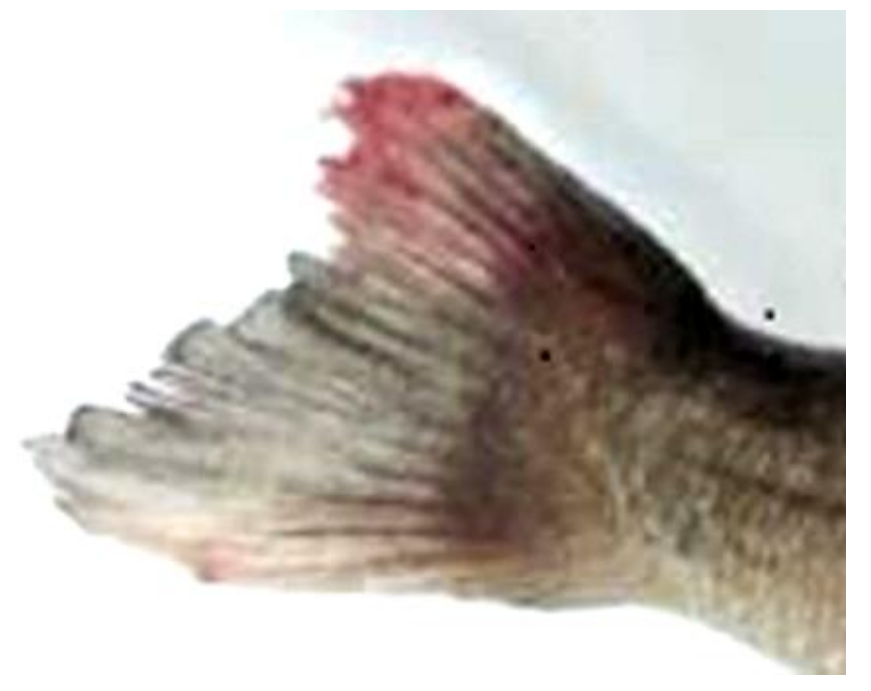

Fig. 1: Fin rot disease in freshwater fish caused by Motile Aeromonads septicaemi.

\section{Geographical Distribution and Host Species}

MAS has worldwide distribution, especially in fresh and brackish water systems. It was documented in 2009 in Alabama (Pridgeon and Klesius 2011), Arkansas and Mississippi. Most fish and many aquatic invertebrates are susceptible to MAS disease, but it can also occur in vertebrates (Dias et al. 2016).

\section{Epizootiology}

Different syndromes with which aeromonds are linked vary widely, depending on the initial stimulus. Outbreaks in salmonids usually occur by sudden increase in water temperature. The relationship of individual pathogenic strain and disease outbreak is a vital factor to evaluate the outcome.

\section{Photobacteriosis}

\section{Etiological Agents and Diseases}

Photobacteriosis or pasteurellosis affects both wild and farmed fish. Its etiological agent is Photobacterium damselae subsp. Piscicida, from Vibrionaceae family, which is a Gram-negative strain. Infected fish show lethargy, loss of equilibrium, high ventilation rates and swim on surface and finally sink before death. Skin infections are secondary to skin abrasion.

\section{Geographical Distribution and Host Species}

Photobacteriosis has a wide range of hosts and has been documented in yellowtail ( $S$. quinqueradiata) in Japan, sea bass (D. labrax), gilthead sea bream ( $S$. aurata), and sole ( $S$. senegalensis and $S$. solea) in Europe, white perch $(M$. americana), striped bass (M. saxatilis), and hybrid striped 
bass (M. saxatilis) in the USA, cobia ( $R$. canadum) in Taiwan and golden pompano (T. ovatus) in China (Wang et al. 2013).

\section{Epizootiology}

This bacterium caused mortality in smaller sized striped bass in western Long Island Sound and Chesapeake. Outbreak of the disease was observed at temperature range of $14-29^{\circ} \mathrm{C}$ and 3-21 salinities. Photobacterium damselae piscicida is an obligate infective agent and can survive outside the host.

\section{Gram-Positive Bacterial Diseases}

\section{Bacterial Kidney Disease (BKD)}

\section{Etiological Agents and Diseases}

The causative agent of Bacterial Kidney Disease (BKD) is Renibacterium salmoninarum, and this is the only specie reported in the genus that adversely affects the sustainable production of salmonid fish. This causative agent is small in size, aerobic, non-acid fast, non-motile, Gram-positive bacteria. The growth of this agent is relatively slow, with the disease chronic in nature and causes mortality in juvenile salmon and prespawning adults (Evelyn 1993). Diseased fish may show no behavioral changes or appear normal, or may exhibit loss of appetite (Pirhonen et al. 200o) and lethargy. Histologically, BKD is considered as a chronic, granulomatous inflammatory disease, characterized by macrophages proliferation in infection sites.

\section{Geographical Distribution and Host Species}

This infection is found in Europe (including Iceland), Chile, North America and Japan. All fish species, belonging to family Salmonidae, are susceptible to this pathogen (Elliott et al. 2014). It has also been documented in cultured ayu $P$. altivelis (family Plecoglossidae) (Nagai and Iida 2002), sea lampreys ( $P$. marinus) (Eissa et al. 2006), Pacific herring (Clupea pallasii) (Evelyn 1993) and sablefish (Anoplopoma fimbria) (Bell et al. 1990).

\section{Epizootiology}

The transmission of $R$. salmoninarum can be horizontally and vertically, and the bacteria have been isolated from both hatchery populations and wild fish populations. BKD can occur over a broad range of temperatures. Infected fish species are main source of the disease. High mortality rate has been recorded in the infective salmonids at 4$20.5^{\circ} \mathrm{C}$ temperatures (Sanders et al. 1978).

\section{Enterococcosis/Lactococcosis}

\section{Etiological Agents and Diseases}

Enterococcus seriolicida/Lactococcus garvieae are Gram positive, facultative non-aerobic, non-motile and ovoid- shaped bacteria that cause Enterococcosis/ Lactococcosis. Diseased fish show loss of orientation, exophthalmia and lethargy. Histologically, pathogen proliferation and necrosis occurs in the affected organs.

\section{Geographical Distribution and Host Species}

This causative organism generally survives in seawater containing high organic matter throughout the year. This disease agent is present in both fresh and marine water and becomes a major disease agent in trout of Portugal, Spain, Turkey, Italy, France, Greece and Israel, where it causes serious production losses.

\section{Epizootiology}

Microorganisms eliminated from diseased fish and contaminated diet are sources of horizontal transmission of disease from fish to fish. Moreover, organisms that survive epizootics may also be source of infection.

\section{Streptococcosis}

\section{Etiological Agents and Diseases}

Streptococcosis is primarily caused by the Gram-positive bacteria, Streptococcus agalactiae, Streptococcus iniae, Streptococcus dysgalactiae, and Streptococcus ictaluri. The characteristics of Streptococcus spp. are given in Table 7. Streptococcus iniae emerged as a major pathogen of farmed and wild fish in the 1990-200o's and has zoonotic potential. S. ictaluri emerged in the catfish industry in the late 200o's in USA, is phylogenetically most similar to $S$. iniae and seems unique with low virulence to channel catfish (Pasnik et al. 2009). Some of the first behavioral changes associated with the disease are lethargy and loss of appetite. Externally, fish often exhibit a darkening of the skin in color; however, acutely infected fish may die due to septicemia with few clinical signs. Dead fish, as well as survivors of recent infections, may have jaw and caudal pustules (LaFrentz et al. 2016; Shoemaker et al. 2017).

\section{Geographical Distribution and Host Species}

It is generally assumed that Streptococcosis has a worldwide distribution, having been described in fish from Europe, the Americas, Middle East, throughout Asia and Australia (Shoemaker et al. 2017). According to Osman et al. (2017), Streptococcosis has been reported globally in wild and cultured fish.

\section{Epizootiology}

The epizootiology of this disease is very complex. Both external environmental conditions and fish stress enhance the chance and severity of Streptococcosis (Xu et al. 2007). The horizontal mode of transmission via water with fish (i.e., carriers) is most likely considered as a source of 
Table 7: Morphological and biochemical characteristics of Streptococcus spp.

\begin{tabular}{ll}
\hline Characteristics & Description \\
\hline Gram-Stain & Gram-positive \\
Growth condition & Facultative anaerobes \\
Morphology & Non-motile, spherical and ovoid in shape, mostly occurs in long chain \\
Voges-Proskauer, & - \\
Acid production from & - \\
sorbitol & + \\
sucrose & + \\
Starch hydrolysis & + \\
Catalse reaction & + \\
\hline
\end{tabular}

$+=$ Positive, $-=$ Negative.

Table 8: Morphological and biochemical characteristics of different Nocardia spp. (Woo and Bruno 2011).

\begin{tabular}{|c|c|c|c|c|}
\hline Characteristics & N. asteroides & N. crassostreae & N. seriolae & N. salmonicida \\
\hline Gram-Stain & Gram-positive & Gram-positive & Gram-positive & Gram-positive \\
\hline Growth condition & Aerobic & Aerobic & Aerobic & Aerobic \\
\hline Morphology & $\begin{array}{l}\text { Irregular shape, } \\
\text { Pleomorphic cell }\end{array}$ & $\begin{array}{l}\text { Irregular shape, } \\
\text { Pleomorphic cell }\end{array}$ & $\begin{array}{l}\text { Irregular shape, } \\
\text { Pleomorphic cell }\end{array}$ & $\begin{array}{l}\text { Irregular shape, } \\
\text { Pleomorphic cell }\end{array}$ \\
\hline Colony colour & Beige & Pale yellow & Pale orange & Orange \\
\hline $\begin{array}{l}\text { Utilization of } \\
\text { sorbitol }\end{array}$ & - & ND & - & + \\
\hline Citrate & + & ND & + & + \\
\hline Acetate & + & ND & + & + \\
\hline Rhamnose & - & ND & - & - \\
\hline Adipic acid & + & ND & ND & ND \\
\hline Decomposition of & & & & \\
\hline Adenine, Elastin & - & ND & - & - \\
\hline Xanthine, Casein & - & - & - & - \\
\hline Urease, Tyrosine & - & - & - & + \\
\hline Aerial hyphae & + & - & - & + \\
\hline
\end{tabular}

ND=Not determined, + = Positive, - = Negative

bacterial infection. The bacteria may survive for extended periods in water and sediment (Nguyen et al. 2002). Vertical transmission of both $S$. iniae and $S$. agalactiae (Pradeep et al. 2016) has been reported in tilapia.

\section{Weissellosis}

\section{Etiological Agents and Diseases}

Weissellosis is caused by Weissella ceti, a Gram-positive, non-endospore forming bacterium.

\section{Geographical Distribution and Host Species}

In 2007, Weissella spp. was first reported in rainbow trout (O. mykiss) in China and has been isolated as the infective agent at trout farms in both the southeastern United States (Welch and Good 2013) and Brazil (Figueiredo et al. 2012). The Weissellosis is rapidly emerging pathogen of farmed rainbow trout. The information about susceptibility of other fish species to this organism remains unknown.

\section{Epizootiology}

For Weissellosis outbreaks, high temperature is the main predisposing factor. It has been recorded on the north side of Carolina, where water temperatures vary through all seasons. The occurrence of seasonal outbreaks of this infection in North Carolina suggested that $W$. cet $i$ has the potency to retain in sites where it has appeared, and could cause an endemic disease. In a production system, it particularly affects the larger fish (0.25-1 kg) compared to smaller fish (Welch and Good 2013). The Weissellosis quickly propagates through some undiscovered mechanisms. The main route of disease transmission remains undiscovered but is the main subject of ongoing investigations.

\section{Mycobacteriosis}

\section{Etiological Agents and Diseases}

It is a chronic to subacute but severe disease of many fish species, caused by Mycobacterium spp. Including Mycobacterium marinum, Mycobacterium fortuitum and Mycobacterium cheloni. Bacterial agents are Grampositives, pleomorphic, acid-fast, aerobic and non-motile rods (Hashish et al. 2018). Emaciation, exophthalmia, lordosis, severe haemorrhages, lethargic behaviour and dermal lesions or loss of scales are major signs at the advanced stage.

\section{Geographical Distribution and Host Species}

This infection continues to be documented worldwide in fish populations. Wild fish, including M. saxatilis (Aronson 1926), G. morhua (Alexander 1913), H. hippoglossus (Sutherland 1922), C. striatus and O. bonariensis, have been reported to show Mycobacteriosis (Hatai et al. 1993). 


\section{Epizootiology}

The mode of transmission of M. marinum between different fish species is not completely understood. The main transmission route of this disease is the oral one through ingestion of diseased dead fish or interaction with diseased fish (El Amrani et al. 2010).

\section{Nocardiosis}

\section{Etiological Agents and Diseases}

Nocardia spp. causes Nocardiosis, which is a lethal granulomatous infection of the muscles, skin and different internal tissues. Four Nocardia spp. have been reported that are Nocardia asteroides, Nocardia salmonicida, Nocardia seriolae and Nocardia crassostreae; their characteristics are given in Table 8. In aquaculture, this infection has caused intense economic losses, particularly in the Asia (Maekawa et al. 2018). Nodules in body organs, with or without multiple skin ulcers, lethargy and anorexia, opacity of cornea and lenticels, intraocular and periocular hemorrhage are common signs of Nocardiosis..

\section{Geographical Distribution and Host Species}

Organisms of Nocardioform caused epizootic ulcerative syndrome in freshwater fish. $N$. seriolae has been reported to cause infection in Japanese sea bass (L. japonicus) and yellow croaker (L. crocea) in China and Taiwan, causing more than $15 \%$ mortality in each species (Wang et al. 2005).

\section{Epizootiology}

The exact route of transmission for Nocardiosis is unknown. Mostly it occurs through oral cavity, but this is not primary route. The transmission of infection through contaminated feed has also been reported.

\section{Intracellular bacterial Diseases}

\section{Piscirickettsiosis}

\section{Etiological Agents and Diseases}

Piscirickettsia salmonis is a non-motile, Gram-negative bacterium, belonging to the family Piscirickettsiaceae (Boone and Castenholz 2001). It causes Piscirickettsiosis, Huito disease, coho salmon septicemia and salmonid rickettsial septicemia. As a fish pathogen, it was the first rickettsia-like pathogenic bacteria to be noted. The small lesions, swollen organs and haemorrhagic ulcers appear on the skin after infection. Affected fish appear dark and lethargic.

\section{Geographical Distribution and Host Species}

This etiological agent has been isolated from Salmonids of Ireland, Chile, Norway and both the east and west coasts of Canada (Fryer et al. 1992; Brocklebank et al. 1992;
Cusack et al. 2002). Other fish species may be susceptible to this organism.

\section{Epizootiology}

Piscirickettsiosis was first reported in 1989 from Salmonids of Chile. The transmission mechanism of this disease is not completely understood but horizontal transmission in both sea and freshwater has been reported (Smith et al. 2004). Vertical transmission can take place in freshwater (Larenas et al. 2003), but this route is not frequently seen in $P$. salmonis. Different strains show totally different levels of virulence.

\section{Epitheliocystis (EP)}

\section{Etiological Agents and Diseases}

Epitheliocystis (EP) is an intracellular gills and skin bacterial infection that results in hypertrophy of the cells of host (Nowak and LaPatra 2006). The causative agents are obligate intracellular, Gram-negative bacteria, mostly from phylum Chlamydiae and are also considered as $\mathrm{\gamma}$ and $\beta$-proteobacteria (Kurahashi and Yokota 2007; Katharios et al. 2015; Seth-Smith et al. 2016). Candidatus Clavichlamydia salmonicola (Karlsen et al. 2008) and Candidatus Piscichlamydia salmonis (Draghi et al. 2004) were isolated from Salmonids, but not from other species of fish. All causative agents of Epitheliocystis are host-specific. Infected fish show white nodular lesions in the gills and skin and disturbed or imbalance gas exchange, ammonia excretion and salt reduction. The clinical signs are loss of appetite, increased mucous production, fish swimming at the surface of water, abnormal swimming pattern and lethargy.

\section{Geographical Distribution and Host Species}

Epitheliocystis was initially reported by Hoffman et al. (1969) in bluegill sunfish (L. macrochirus). This disease has been recorded in about 90 fish species from 14 countries (Nylund et al. 1998); the infected fish species include: brown trout (S. trutta) (Guevara et al. 2016); catadromous fish such as barramundi (L.calcarifer); marine fish species e.g. broad-nosed pipefish (S. typhle) (Fehr et al. 2013) or sharpsnout sea bream (D. puntazzo) (Katharios et al. 2008); and freshwater fish species like silver perch (B. bidyanus) (Frances et al. 1997), white sturgeon (A. transmontanus) (Groff et al. 1996), carps (family Cyprinidae) (Nowak and LaPatra 2006) and striped catfish ( $P$. hypophthalmus) (Sood et al. 2017). The Chondrichthyes species like leopard shark ( $T$. semifasciata) can also be infected by this pathogen (Polkinghorne et al. 2010).

\section{Epizootiology}

Infection carrying fish are considered to be the main source for horizontal transmission. Wild Salmonids may be the source of the disease in farmed Salmonids, with 
translocation or stocking actions of fish may be contributing to transmission (Guevara et al. 2016). From eggs to fingerlings, vertical transmission has been supposed to occur in barramundi. The amoebae have been considered as a vector in the past (Corsaro and Greub 2006). Although other species of chlamydiae grow in amoebae, so far no infection agents of this disease have been able to be cultured in amoebae.

\section{Francisellosis}

\section{Etiological Agents and Diseases}

Francisellosis, caused by the Francisella species, has been documented recently; severe granulomatous disease has also been reported to be caused by Francisella spp. F. noatuensis, $F$. piscicida and F. victoria. Francisella spp. are non motile, Gram-negative, facultative intracellular bacterial pathogen and pleomorphic coccobacilli, having 0.5-1.5 $\mu \mathrm{m}$ diameter. Phylogenetic data have classified this organism to the genus Francisella and also classified it in the $\gamma$ sub-division of the proteobacteria. Infected fish can show different clinical signs, such as exophthalmia, loss of appetite, lethargy, petechiae, abnormal behavior of swimming, dark colored body and haemorrhagic nodules on the skin.

\section{Geographical Distribution and Host Species}

In tilapia fish, this disease has been reported from continental US, Latin America, Taiwan and Hawaii, three lined grunt of Japan, cod in Norway, Atlantic salmon of Chile (Woo and Bruno 2011). Francisella species have global distribution and broad range of host species.

\section{Epizootiology}

The overall life cycle of Francisella spp. is not fully known, but is likely to be similar to Francisella species of mammals. The bacterial agent is present probably in the water column and mechanism of transmission described in tilapia is horizontal. Both fresh and marine fish show the infection, but bacterium strains isolated from these different geographic sites and hosts may vary. The vectors role or vertical transmission of infection is still unknown.

\section{Prevention and Control of Bacterial Diseases}

Disease prevention is always preferred and more profitable than disease treatment. Several techniques have been used to prevent and control fish infections.

\section{Conventional Preventive and Control Measures}

\section{Standard Hygienic Measure}

To overcome disease outbreaks, fish farms principally rely on preventative measures by allowing the entry of pathogenic free broodstocks, screening and sterilization of stock and culling of infected populations (Elliott et al.
1989). Many infections like BKD, furunculosis and ERM do not always show themselves in clinical form and transfer the infective agent with the movements of fish. So, it is compulsory to apply transportation restrictions. By quarantine measures and improvement of water quality and feed, the disease can be controlled because dietary supplements like vitamin $\mathrm{A}, \mathrm{E}$ and $\mathrm{C}$ enhance immunity against $A$. hydrohila (Sobhana et al. 2002). It is essential to ensure that no infectious agents can enter the fish farm from any equipment, vehicles, visitors and staff. Better management of hatchery is the foremost strategy to prevent Aeromonads spp. In hatcheries that reuse water, both ozonation and filtration conducted with UV irradiation (Colberg and Lingg 1978) can destroy the $A$. hydrophila.

\section{Disinfectants}

Disinfection of fish farms in confined places can be done easily (Toranzo et al. 2005), otherwise it is challenging to prevent and control disease distribution (FAO 2016). Various chemicals are used according to the type of organisms, their life cycle stage, the culture method and intensity of culture (Gomez-Gil et al. 2000). For disinfectation, $5 \%$ phenol, $\mathrm{KMNO}_{4}(5 \mathrm{mg} / \mathrm{l})$, iodine solutions, $1 \%$ sodium hypochlorite, formaldehyde and glutaraldehyde are advised. Moreover, malachite green and $\mathrm{CuSO}_{4}$ are also used but in aquaculture, overdoses of all chemicals may lead to serious toxicity in fish (Bornø and Colquhoun 2009).

\section{Antibiotics}

Various antibiotics have been used in aquaculture, but it is not suggested to entirely depend on them because their use has many disadvantages, such as the short period of protection, cost of antibiotics, the necessity for continual treatments during the disease outbreak, the trouble caused by production of resistant strains and increased noxious residual material in carcasses (Miranda and Zemelman 2002). Oxytetracycline, sulfadimethoxine, tetramycine and tetracycline are among the most commonly used antibiotics in fish production. Previous studies have shown that Edwardsiella spp. are susceptible to different antibiotics, such as cephalosporins, aminoglycosides, quinolones, sulphamethoxazole, penicillins, aztreonam, ciprofloxacin, antibiotic beta lactamase inhibitor agents and nitrofurantoin (Jnaneshwara et al. 2016). Chloramphenicol, derivatives of nalidixic acid, ampicillin, sulfonamides and nitrofuran derivatives are usually used to control vibriosis (Aoki et al. 1984). The use of various antibiotics enhanced the rate of antimicrobial resistant strains, as well as presence of residual substances of drugs in the food, which are the main issues that have prompted scientists to investigate for other effective and safe techniques (Pal 2015). Therefore, aquaculturists are focusing on searching alternative techniques to control pathogens (Taoka et al. 2006). 


\section{Vaccination}

Vaccines are killed bacteria or bacterins acquired from a particular strain of bacteria subjected to formalin deactivation. Vaccinated fish can be a carrier of the disease because the bacteria cannot be eliminated totally from fish body. Conventionally, vaccines are administered mainly by injections, that causes stress to the fish and also stimulates the humoral immune responses, and provides security against the disease for short periods. Thus, the aquaculturists are searching for other eco-friendly and effective methods for treatment and protection of fish against pathogens (Dahiya et al. 2010).

\section{Recent Prevention and Control Measures}

\section{Probiotics}

Probiotics are characterized as dead or live microorganisms, or a constituent of the beneficial microorganism that works through variable modes of action, conferring advantageous effects to the host or its environment. Various probiotics have been used to control fish diseases. Their selection depends mainly on detection of power to kill the pathogens by using tests (agar well diffusion) to analyze the released inhibitory matter. Probiotics are mainly used in dry form as food supplements, or by adding into the drinking water. The liquid form is fast-acting and shows its effects earlier than those of the dry form (Nageswara and Babu 2006). It has been reported that the use of probiotics (Bacillus subtilis and Bacillus licheniform) defends rainbow trout against infections of Y. ruckeri (Raida et al. 2003).

\section{Antagonist of Quorum Sensing (QS)}

Quorum sensing (QS) is gene expression regulation as a result of connection between infective cells. Many species of bacteria are using this mechanism to modulate their action. Use of probioticsinduces disturbances of QS, which has used a possible anti-infective strategy in aquaculture and fisheries (Defoirdt et al. 2004). The halogenated furanones can defend rainbow trout from the diseases caused by organisms of genus Vibrio (Tinh et al. 2007).

\section{Immunomodulation}

Probiotics are also known as powerful immunostimulants that regulate the immunity of the host against diseases by increasing the rate of phagocytosis and leucocytes counts. Probiotics also enhance the antimicrobial peptides formation (Mohapatra et al. 2012).

\section{Improving Water Quality (Bioremediation)}

Water quality can be improved through bioremediation or by adding Gram-positive bacteria, because they convert organic matter into $\mathrm{CO}_{2}$ (carbon dioxide), while the Gramnegatives convert organic matter directly into biomass of bacteria and infections (Balcazar et al. 2006). Nitrite and ammonia toxicity in culture systems can be destroyed by using nitrifying bacteria in culture systems. Maintenance of pathogen-free good water quality,minimizing organic materials and stress by avoiding overcrowding and low dissolved oxygen, and effective cleanliness of fish production tanks by instantly removal of dead fish prevents bacterial cold water disease.

\section{Ozone Nanobubble Treatment}

Pathogenic bacteria in water usually enhance bacterial disease outbreaks in cultured fish. Ozone gas nanobubble $\left(\mathrm{NB}-\mathrm{O}_{3}\right)$ technology is not only a beneficial disinfection method, but also supplies dissolved oxygen (DO) in freshwater aquaculture, and it is not harmful to the fish in low dosage. Jhunkeaw et al. (2021) reported that upon NB$\mathrm{O}_{3}$ treatment, the number of bacterial colonies reduced rapidly during $10 \mathrm{~min}$ following three times continuous exposure in the treated tanks. Before the treatment, the total bacterial density in the fish-cultured water was 6.93 $\times 10^{5} \pm 7.81 \times 10^{5} \mathrm{CFU} / \mathrm{mL}$ and $42.94 \%$ of the bacteria were inactivated after the $\mathrm{NB}-\mathrm{O}_{3}$ exposure for $10 \mathrm{~min}$. When the same method was followed, 84.94 to $99.27 \%$ reduction in bacterial loads was observed in treated tanks (Fig. 2).

\section{Prebiotics}

Prebiotics are originated from cell wall components of yeast and are non-digestible. They limit the presence of bacterial pathogens in fish farms and improve the intestinal health-boosting bacteria (lactobacillus). Rodrigues-Estrada et al. (2008) reported that diet supplementation with prebiotics improved growth, phagocytic and hemolytic activity, survival of fish in a document with $V$. anguillarum. Rainbow trout $(O$. mykiss) showed better growth rate, antibodies, and activity of lysozyme after diet supplemented with prebiotics (Staykov et al. 2007). Sink et al. 2007 stated golden shiners fed the diets having prebiotic (dairy-yeast) showed lower infection associated with $F$. columnare.

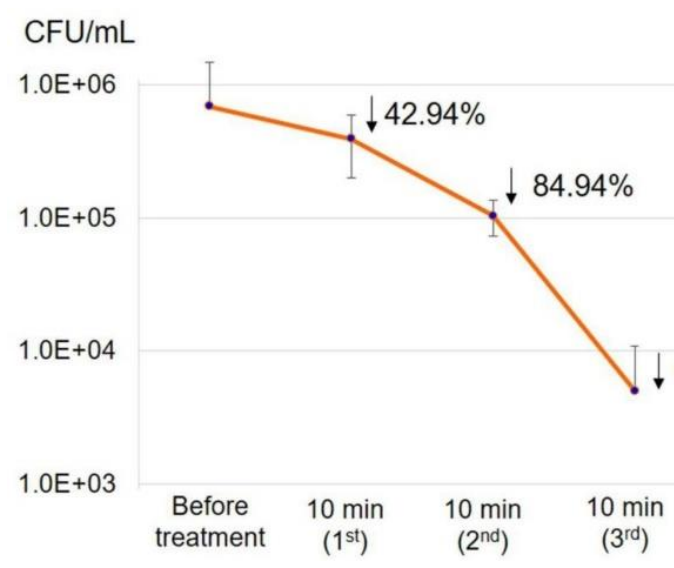

Fig. 2: Total bacterial colony counts from fish-cultured water upon exposure to $\mathrm{NB}-\mathrm{O}_{3}$, for $10 \mathrm{~min}$, three times continuously. Arrows indicate \% reduction of bacterial loads compared to the starting bacterial concentration. Bars = standard deviation (SD) from 3 replicates (Jhunkeaw et al. 2021). 


\section{Synbiotic}

Synbiotic is an assemblage of both probiotics and prebiotics, which increases the survival rate and spreading of live microbiota in the gastro-intestinal tract. The use of $E$. faecalis in fish feed offers a variety of advantages regarding the improvement in immunity and fish survival with $V$. anguillarum. The synbiotic feeding results in significantly good consequences than individual application of prebiotic and probiotic (Gatlin and Peredo 2012).

\section{Bio Vaccines}

\section{Living Attenuated Vaccines}

The live attenuated vaccine application in aquaculture was started in 1990 (Sun et al. 2010). These vaccines are live and attenuated organisms and establish less infection, resulting in the stimulation of humoral and mucosal immunity. Random and direct strategies can be used to induce certain mutations into bacterial pathogens to achieve better attenuation. Sometimes, mutations are reversible, particularly when bacterial pathogens become mutated by passages or by chemicals. This condition poses a serious risk for both environment and the host. To reduce such problems, bacteria should be mutated after genes inactivation involved in biochemical pathways. Examples of targeted metabolic ways to produce attenuated vaccines include: purine biosynthesis, aromatic amino acid biosynthesis, galactose epimerase, adenylate cyclase and capsule biosynthesis. These mutant bacteria were unable to proliferate and increase their abundance to induce infection; they cannot live long enough to cause infections (Roberts et al. 1990). Original live attenuated vaccines have been prepared against $L$. anguillarum and $Y$. ruckeri pathogens by deletion of their aroA and aroC genes. Vaccinated flounders ( $P$. olivaceus) with 107 $\mathrm{CFU} / \mathrm{ml}$ attenuated strain $(\Delta$ aroA $\Delta \mathrm{esrB})$ showed $100 \% \mathrm{RPS}$ against $107 \mathrm{CFU} / \mathrm{ml}$ E. tarda (Li et al. 2015). Mohd-Aris et al. (2019) successfully formulated mutant $V$. harveyi by deletion of protease, as a candidate live-attenuated vaccine against vibriosis in E. fuscoguttatus.

\section{Live Feeds Bio-Encapsulated Oral Vaccine}

The encapsulation is practically used either to stop the escaping of antigen from the pelleted feed, or for its protection from the acidic medium of the fish stomach. This type of feed releases the immunizing agent into the fish digestive tract, which seems to be the most fascinating method for vaccines treatment. It further lessens the fish handling, that ultimately reduces the stress of fish and is most appropriate for mass immunization against vibriosis (Rombout 1989).

\section{Nano-Bio-Encapsulated Vaccine}

The application of nanoparticles as adjuvant and economic delivery systems in vaccine development of fish is increasing due to their nano size. The benefits of nanovaccines include; site specific delivery of antigens, antigens protection from degradation, enhanced bioavailability and reduced side effects (Zolnik et al. 2010).

\section{Bacteriophages Therapy}

The most significant biological control method for bacterial pathogens in fisheries and aqua-farming is through bacteriophages, which are nontoxic for animals and humans and can be used safely as therapeutic agents. In different fields of medical sciences and biotechnology, phages have been applied for prevention of bacterial infection, management, rapid detection and biocontrol of diseases (Haq et al. 2012). Additionally, bacteriophages are more specific and can only infect cells of bacteria that have specific receptors sites (Kutter et al. 2004). Hsu et al. (2000) and Castillo et al. (2011) utilized phages in water of fish pond against A. hydrophila and F. Pshychrophilum, respectively. Imbeault et al. (2006) suggested that bacteriophage treatments should have multiple phages against $A$. salmonicida to control target pathogens, as well as resistant ones. Proper phage doses and phage characters are essential for efficient therapy.

\section{Conclusion}

This chapter summarizes the knowledge about the characteristics, geographical distribution, host range, and epizootiology of common fish pathogenic bacteria, but new etiological agents are being identified every year. The higher disease outbreaks occurred in both larval and juvenile stages of the fish. The most common fish bacterial species that can cause diseases belong to the genera Vibrio, Flavobacterium, Aeromonas, Yersinia, Edwardsiella, lactococcus, Streptococcus, Renibacterium and Mycobacterium. There are flourishing indications that different infective bacterial species have broad geographic distribution and host range, causing the emergence of new bacterial pathogens. At last, the conventional and modern disease prevention methods and their control strategies are also addressed. Hence, basic knowledge of pathogen profiles and diseases, in addition to their fundamental economic background of the operational costs, is a primary requisite in the designing of strategies to control most common bacterial diseases. It is strongly recommended that all the possible limitations in control methods must be addressed critically before employing in the aquaculture sectors. Comparative pathogenomics provide important information that how similar bacterial species show different virulence, adapted to various ecological niches and new host species. The determination of main virulence factors in disease-causing strains can assist us to plan effective therapeutic and vaccines strategies to control fish diseases.

\section{REFERENCES}

Abayneh et al., 2013. Edwardsiella piscicida sp. Nov. A novel species pathogenic to fish. Journal of Applied Microbiology 114: 644-654. 
Alexander DM, 1913. A review of piscine tubercle, with a description of an acid-fast bacillus found in the cod. Transactions of Liverpool Biology Society 27: 219-226.

Aoki et al., 1984. Drug resistance and R plasmids in Vibrio anguillarum isolated in cultured ayu (Plecoglossus altivelis). Micobiology and Immunology 28: 1-9.

Aronson JD, 1926. Spontaneous tuberculosis in salt water fish. Journal of Infectious Diseases 39: 315-320.

Austin B and Austin DA, 2007. Bacterial fish pathogens. In: Diseases of Farmed and Wild Fish. 4th Edition. Springer-Praxis Publishing, New York-Chichester.

Austin B and Austin DA, 1987. Enterobacteriaceae representatives. Bacterial Fish Pathogens. In: Disease in Farmed and Wild Fish. Ellis Horwood Ltd., Chichester England, pp: 6-224.

Bagge J and Bagge O, 1956. Vibrio anguillarum som arsag til ulcussygdom has torsk (Gadus callarias L.) (Vibrio anguillarum as cause of the ulcer disease in cod). Nordisk Veterinaer Medicin 8: 481-492.

Balcazar et al., 2006. The role of probiotics in aquaculture. Veterinary Microbiology 114: 173-186.

Bell et al., 1990. Pathology of experimental infections of the sablefish Anoploma fimbria (Pallas), with Renibacterium salmoninarum, the agent of bacterial kidney disease in salmonids. Journal of Fish Diseases 13: 355-367.

Bernardet JF and Bowman JP, 2006. The genus Flavobacterium. In: The prokaryotes. Berlin: Springer; pp: 481-531.

Boone DR and Castenholz RW, 2001. Taxonomic outline of the Archaea and Bacteria, Bergey's Manual of Systematics Bacteriology, Volume 1, $2^{\text {nd }}$ Edition. Springer, New York, pp: 155-166.

Bornø G and Colquhoun D, 2009. Classical furunculosis (in Norwegian) Fact sheet, Norwegian Veterinary Institute.

Brocklebank et al., 1992. Septicemia suspected to be caused by a rickettsia-like agent in farmed Atlantic salmon. The Canadian Veterinary Journal 33: 407-408.

Castillo et al., 2011. Diversity of Flavobacterium psychrophilum and the potential use of its phages for protection against bacterial cold water disease in salmonids. Journal of Fish Disease 35: 193-201.

Castillo et al., 2017. First isolation and characterisation of Flavobacterium psychrophilum from diseased rainbow trout (Oncorhynchus mykiss) farmed in Mexico. Bulletin of the European Association of Fish Pathologists 37: 23-30

Corsaro D and Greub G, 2006. Pathogenic potential of novel Chlamydiae and diagnostic approaches to infections due to these obligate intracellular bacteria. Clinical Microbiology Reviews 19: 283-297.

Colorni A, 2004. Diseases of Mediterranean fish species: Problems, research and prospects. Bulletin of European Association of Fish Pathologists 24: 22-32.

Cusack RR et al., 2002. Rickettsial infection in farmed Atlantic salmon in eastern Canada. The Canadian Veterinary Journal 43: 435-440.

Colberg PJ and Lingg AJ, 1978. Effect of ozonation on microbial fish pathogens, ammonia, nitrate, nitrite and biological oxygen demand in simulated reuse hatchery water. Journal of the Fisheries Research Board of Canada 35: 1290-1296.

Dahiya et al., 2010. Use of probiotics as an alternative method of disease control in aquaculture. Biosphere 2: 52-57.

Declercq et al., 2013. Columnaris disease in fish: A review with emphasis on bacterium-host interactions. Veterinary Research 44: 27.

Dias et al., 2016. Lethal dose and clinical signs of Aeromonas hydrophila in Arapaima gigas (Arapaimidae), the giant fish from Amazon. Veterinary Microbiology 188: 12-15.

Draghi et al., 2004. Characterization of "Candidatus piscichlamydia salmonis" (order Chlamydiales), a chlamydia-like bacterium associated with epitheliocystis in farmed Atlantic salmon (Salmo salar). Journal of Clinical Microbiology 42: 5286-5297.

Eissa et al., 2006. First record of Renibacterium salmoninarum in the sea lamprey (Petromyzon marinus). Journal of Wildlife Diseases 42: 556-56o.

El Amrani et al., 2010. Upper extremity Mycobacterium marinum infection. Orthopedic Traumatology Surgery Research 96: 706-711.

Elliott DG et al., 2014. Vaccination against bacterial kidney disease. In: Gudding R, Lillehaug $\mathrm{A}$ and Evensen $\varnothing$, (editors) Fish Vaccination. WileyBlackwell, Oxford, UK, pp: 255-272.

Elliott et al., 1989. Developments in the control of bacterial kidney disease of salmonid fishes. Diseases of Aquatic Organisms 6: 201-215.

Evelyn TPT, 1993. Bacterial kidney disease. In: Inglis V, Roberts RJ and Bromage NR, (editors) Bacterial Diseases of Fish. Halsted Press, New York, USA, pp: 177-195

FAO, 2016. He State of World Fisheries and Aquaculture: Contributing to food security and Nutrition for all. Rome, p: 200

Farmer JJ and McWhorter AC, 1984. Genus X. Edwardseilla, Ewing and McWhorter (1965). In: Krieg NR and Holt JG, (eds) Bergey,s Manual of Systematics Bacteriology, Vol. 1. Williams and Wilkins, Baltimore, USA, pp: 486-491.

Fehr et al., 2013. Candidatus Syngnamydia venezia, a novel member of the phylum Chlamydiae from the broad nosed pipefish, Syngnathus typhle. PLoS ONE 8: e70853. https://doi.org/10.1371/journal.pone.0070853.

Figueiredo et al., 2012. Weissella sp outbreaks in commercial rainbow trout (Oncorhynchus mykiss) farms in Brazil. Veterinary Microbiology 156: 359-366.

Frances et al., 1997. Epitheliocystis in silver perch, Bidyanus bidyanus. Journal of Fish Diseases 20: 453-457.

Fryer et al., 1992. Piscirickettsia salmonis gen. nov.; sp. nov. the causative agent of an epizootic disease in salmonid fishes. International Journal of Systematic Bacteriology 42: 120-126.

Garcia et al., 2007. Hematology of Piaractus mesopotamicus fed diets supplemented with vitamins $\mathrm{C}$ and E, challenged by Aeromonas hydrophila. Aquaculture 271: 39-46. 
Gatlin DM and Peredo AM, 2012. Southern Regional Publication Centre; Prebiotics and probiotics: definition and application. SRAC Publication No. 4711.

Gomez-Gil et al., 2000. The use and selection of probiotic bacteria for use in the culture of larval aquatic organisms. Aquaculture 191: 259-270.

Good et al., 2010. A prospective matched nested casecontrol study of bacterial gill disease outbreaks in Ontario, Canada government salmonid hatcheries. Preventative Veterinary Medicine 95: 152-157.

Grimont et al., 1980. Edwardsiella hoshinae, a new species of Enterobacteriaceae. Current Microbiology 4: 347-351.

Groff et al., 1996. Epitheliocystis infection in cultured white sturgeon (Acipenser transmontanus): Antigenic and ultrastructural similarities of the causative agent to the chlamydiae. Journal of Veterinary Diagnostic Investigation, 8: 172-180.

Guevara et al., 2016. Epitheliocystis distribution and characterization in brown trout (Salmo trutta) from the headwaters of two major European rivers, the Rhine and Rhone. Frontiers in Physiology 7: 131.

Davis HS, 1926. A new gill disease of trout. Transactions of the American Fisheries Society 56: 156-16o.

Haq et al., 2012. Bacteriophages and their implications on future biotechnology: A review. Virology Journal 9: 18.

Hashish et al., 2018. Mycobacterium marinum infection in fish and man: epidemiology, pathophysiology and management: A review. Veterinary Quarterly. 38: 346.

Hatai et al., 1993. Mycobacterium infection in pejerrey, Odonthestes bonariensis Cuvier and Valenciennes. Journal of Fish Diseases 16: 397-402.

Hawke JP, 1979. A bacterium associated with disease of pond cultured channel catfish. Journal of the Fisheries Research Board of Canada 36: 1508-1512.

Hawke et al., 1981. Edwardseilla ictaluri sp. Nov. The causative agent of enteric septicaemia of catfish. International Journal of American Fisheries Society 115: 232-235.

Hoffman et al., 1969. Epitheliocystis, a new infectious disease of the bluegill (Lepomis macrochirus). Antonie van Leeuwenhoek 35: 146-158.

Holt JG et al., 1994. Bergey's manual of determinative bacteriology, 9th Edition. Williams \& Wilkins, Baltimore, USA, pp: 175-289.

Holt RA et al., 2012. Coldwater disease. AFS Fish Health Section Blue Book.

Hsu et al., 200o. Control of the eel (Anguilla japonica) pathogens, Aeromonas hydrophila and Edwardsiella tarda, by bacteriophages. Journal of Fish Society Taiwan 27: 21-31.

Imbeault et al., 2006. Using bacteriophage to prevent furunculosis caused by Aeromonas salmonicida in farmed brook trout. Journal of Aquatic Animal Health 18: 203-214.

Jnaneshwara et al., 2016. Edwardsiella tarda: An uncommon causative agent of cellulitis. International Journal of Current Microbiology and Applied Science 5: 627-630.
Jhunkeaw et al., 2021. Ozone nanobubble treatment in freshwater effectively reduced pathogenic fish bacteria and is safe for Nile tilapia (Oreochromis niloticus). Aquaculture 534: 736286.

Katharios et al., 20o8. Severe mortality in mesocosmreared sharpsnout sea bream Diplodus puntazzo larvae due to epitheliocystis infection. Diseases of Aquatic Organisms 82: 55-60.

Katharios et al., 2015. Environmental marine pathogen isolation using mesocosm culture of sharpsnout seabream: striking genomic and morphological features of novel Endozoicomonas sp. Scientific Reports 5: 17-609.

Kubota SS and Takakuwa M, 1963. Studies on the disease of marine culture fishes. 1. General description and preliminary discussion of fish diseases at Mie Prefecture. Journal of the Faculty of Fisheries of the Prefectural University of Mie 6: 107-124.

Kumar et al., 2015. Yersinia ruckeri, the causative agent of enteric redmouth disease in fish. Veterinary Research 46: 1-10.

Kurahashi M and Yokota A, 2007. Endozoicomonas elysicola gen. nov., sp. nov., a c-roteobacterium isolated from the sea slug Elysia ornate. Syst. Applied Microbiology 30: 202-206.

Kutter E et al., 2004. Bacteriophages: Biology and applications. CRC Press; p: 528.

LaFrentz et al., 2016. Controlled challenge experiment demonstrates substantial additive genetic variation in resistance of Nile tilapia (Oreochromis niloticus) to Streptococcus iniae. Aquaculture 458: 134-139.

Larenas et al., 2003. Experimental vertical transmission of Piscirickettsia salmonis and in vitro study of attachment and mode of entrance into the fish ovum. Diseases of Aquatic Organisms 56: 25-30.

$\mathrm{Li}$ et al., 2015. Generation and evaluation of virulence attenuated mutants of Edwardsiella tarda as vaccine candidates to combat edwardsiellosis in flounder (Paralichthys olivaceus). Fish Shellfish Immunology 43: 175-180.

Maekawa et al., 2018. Current knowledge of nocardiosis in teleost fish. Journal of Fish Disease 41: 413-419.

Miranda CD and Zemelman R, 2002. Bacterial resistance to oxytetracycline in Chilean salmon farming. Aquaculture 212: 31-47.

Mohapatra et al., 2012. Aquaculture and stress management: A review of probiotic intervention. Journal of Animal Physiology and Animal Nutrition 14: 1-26.

Mohd-Aris et al., 2019. Vibrio harveyi protease deletion mutant as a live attenuated vaccine candidate against vibriosis and transcriptome profiling following vaccination for Epinephelus fuscoguttatus. Aquaculture International 27: 125.

Nagai T and Iida Y, 2002. Occurrence of bacterial kidney disease in cultured ayu. Fish Pathology 37: 77-81.

Nageswara PV and Babu DE, 2006. Probiotics as an alternative therapy to minimize or avoid antibiotics use in aquaculture. Fishing Chimes 26: 112-114.

Nguyen et al., 2002. Ecological investigation of Streptococcus iniae isolated in cultured Japanese 
Flounder, Paralichthys olivaceus using selective isolation procedures. Aquaculture 205: 7-17.

Nowak BF and LaPatra SE, 2006. Epitheliocystis in fish. Journal of Fish Disease 29: 573-588.

Nylund et al., 1998. A morphological study of the epitheliocystis agent in farmed Atlantic salmon. Journal of Aquatic Animal Health 10: 43-55.

OIE, 2006. Enteric septicaemia of catfish. In: Manual of Diagnostic Tests for Aquatic Animals.

Osman et al., 2017. Characterization and susceptibility of streptococci and enterococci isolated from Nile tilapia (Oreochromis niloticus) showing septicaemia in aquaculture and wild sites in Egypt. BMC Veterinary Research 13: 357.

Ostland et al., 1994. Characteristics of Flavobacterium branchiophilum, the cause of salmonid bacterial gill disease in Ontario. Journal of Aquatic Animal Health 6: 13-26.

Park et al., 2012. Pathogenesis of and strategies for preventing Edwardsiella tarda infection in fish. Veterinary Research 43: 1-67.

Pasnik et al., 2009. Pathogenicity of Streptococcus ictalurid to channel catfish. Journal of Aquatic Animal Health 21: 184-188.

Pirhonen et al., 200o. Appetite of Chinook salmon (Oncorhynchus tshawytscha) naturally infected with bacterial kidney disease. Aquaculture 189: 1-10.

Plumb JA and Vinitnantharat S, 1989. Biochemical, biophysical, and serological homogeneity of Edwardseilla ictaluri infection in channel catfish. Journal of Aquatic Animal Health 2: 194-197.

Polkinghorne et al., 2010. Novel Chlamydiales associated with epitheliocystis in a leopard shark Triakis semifasciata. Diseases of Aquatic Organisms 91: 75-81.

Pradeep et al., 2016. Evidence of vertical transmission and tissue tropism of streptococcosis from naturally infected red tilapia (Oreochromis spp.). Aquaculture Reports 3: 58-66.

Pridgeon JW and Klesius PH, 2011. Molecular identification and virulence of three Aeromonas hydrophila isolates cultured from infected channel catfish during a disease outbreak in west Alabama (USA) in 2009. Diseases of Aquatic Organisms 94: 249-253.

Raida et al., 2003. Enhanced resistance of rainbow trout, Oncorhynchus mykiss (Walbaum), against Yersinia ruckeri challenge following oral administration of Bacillus subtilis and B. licheniformis (BioPlus2B). Journal of Fish Disease 26: 495-498.

Ravi et al., 2007. Screening and evaluation of probiotics as a biocontrol agent against pathogenic vibrio in marine aquaculture. Letters in Applied Microbiology 45: 219223.

Roberts et al., 1990. Construction and characterization in vivo of Bordetella pertussis aroA mutants. Infection and Immunity 58: 732-739.

Rodrigues-Estrada et al., 2008. Studies the effects of mannan-oligosaccharides, Enterococcus faecalis, and poly hydrobutyric acid as immune stimulant and growth promoting ingredients in Rainbow Trout diets. 5th World Fisheries Congress, Yokohama, Japan, 2025 October 2008, pp: 158.

Rombout et al., 1989. Immunological importance of the second gut segment of carp. Systemic and/or mucosal immune responses after immunization with soluble or particulate antigen. Iournal of Fish Biology 35: 179-186.

Rucker RR, 1963. Status of fish diseases and relation to production. Report of the Second Governors Conference on Pacific Salmon, Seattle, pp: 98-101.

Sanders et al., 1978. Relation of water temperature to bacterial kidney disease in coho salmon (Oncorhynchus kisutch), sockeye salmon (O. nerka), and steelhead trout (Salmo gairdneri). Journal of the Fisheries Research Board of Canada 35: 8-11.

Seth-Smith et al., 2016. Emerging pathogens of gilthead seabream: Characterisation and genomic analysis of novel intracellular $\beta$-proteobacteria. The ISME Journal volume 10, pages1791-1803.

Shao et al., 2015. Phylogenomics characterization of a highly virulent Edwardsiella strain ETo8o813T encoding two distinct $\mathrm{T}_{3} \mathrm{SS}$ and three T6SS gene clusters: Propose a novel species as Edwardsiella anguillarum Sp. Nov. Systematic and Applied Microbiology 38: 36-47.

Shoemaker CA et al., 2017. Streptococcus iniae and Streptococcus agalactiae. In: PTK Woo and R. Cipriano (editors), Fish Viruses and Bacteria: Pathobiology and Protection. CABI, Inc., pp: 298-313.

Shotts EBJR, 1994. Furunculosis. In: Thoesen JC (ed), Blue Book, Version 1. Suggested Procedures for the Detection and Isolation of Certain Finfish and Shellfish Pathogens. Bethesda, Maryland: American Fisheries Society, Fish Health Section.

Sink et al., 2007. Mortality rates in golden shiners fed high-fat diets with or without a dairy-yeast prebiotic before challenge with Flavobacterium columnare. North American Journal of Aquaculture 69: 305- 308.

Smith et al., 2004. Experimental infection of coho salmon Oncorhynchus kisutch by exposure of skin, gills and intestine with Piscirickettsia salmonis. Diseases of Aquatic Organisms 61: 53-57.

Sobhana et al., 2002. Effect of dietary vitamin $C$ on the disease susceptibility and inflammatory response of mrigal, Cirrhinus mrigala (Hamilton) to experimental infection of Aeromonas hydrophila. Aquaculture 207: $225-238$.

Sood et al., 2017. Candidatus Actinochlamydia pangasiae sp. nov. (Chlamydiales, Actinochlamydiaceae), a bacterium associated with epitheliocystis in Pangasianodon hypophthalmus. Journal of Fish Diseases 41: 281-290.

Staykov et al., 2017. Effect of amannan oligosaccharide on the growth performance and immune status of rainbow trout (Oncorhynchus mykiss). Aquaculture International 15: 153-161.

Pal S, 2015. Phage therapy, an alternate disease control in Aquaculture: A review on recent advancements. IOSR Journal of Agriculture and Veterinary Sciences 8: 68-81.

Sun et al., 2010. Identification of an Edwardsiella tarda surface antigen and analysis of its immune-protective 
potential as a purified recombinant subunit vaccine and a surface-anchored subunit vaccine expressed by a fish commensal strain. Vaccine 28: 6603-66o8.

Sutherland PL, 1922. A tuberculosis-like disease in a saltwater fish (halibut) associated with the presence of an acid-fast tubercle-like bacillus. Journal of Pathology and Bacteriology 25: 31-35.

Taoka et al., 2006. Use of live and dead probiotic cells in tilapia (Oreochromis niloticus). Fish Science 72: 755766.

Thiyagarajan et al., 2014. A study on the control of Aeromonas hydrophila infection in the cat fish by medicinal plants. Scholars Academic Journal of Biosciences 2: 144-150.

Tinh et al., 2007. A review of the functionality of probiotics in the larviculture food chain. Marine Biotechnology 10: 1-12.

Toranzo AE et al., 2005. A review of the main bacterial fish diseases in mariculture systems. Agriculture 246: 37-61.

Vatsos et al., 2001. Adhesion of the fish pathogen Flavobacterium psychrophilum to unfertilized eggs of rainbow trout (Oncorhynchus mykiss) and n-hexadecane. Letters in Applied Microbiology 33: 178-182.

Wang et al., 2013. "Studies on the isolation of Photobacterium damselae subsp. Piscicida from diseased golden pompano (Trachinotus ovatus Linnaeus) and antibacterial agents sensitivity," Veterinary Microbiology 162: 957-963.

Wang et al., 2005. Nocardiosis in large yellow croaker, Larimichthys crocea (Richardson). Journal of Fish Disease 28: 339-345.

Waltman WD and Shotts EB, 1986. Antimicrobial susceptibility of Edwardseilla ictaluri. Journal of Wild life Diseases 22: 173-177.

Welch TJ and Good CM, 2013. Mortality associated with weissellosis (Weissella sp.) in USA farmed rainbow trout: Potential for control by vaccination. Aquaculture 388: 122-127.

Wiik R and Edidius E, 1986. Genetic relationships of Vibrio salmonicida sp.nov. To other fish pathogen vibrios. International Journal of Systematic Bacteriology 36: 521-530.

Woo PTK and Bruno DW, 2011. Fish Disease and Disorders: viral, bacterial and fungal infections. Volume 3. CABI Publishing, New York, USA.

$\mathrm{Xu}$ et al., 2007. Evaluation of the link between gyrodactylosis and streptococcosis of Nile tilapia, Oreochromis niloticus (L.). Journal of Fish Diseases 30: 233-238.

Zolnik et al., 2010. Nanoparticles and immune systems. Endocrinology 151: 458-465. 